\title{
Terengganu Schools Extent of Computer Literacy and Internet Usage
}

\author{
Gopala Krishnan Sekharan Nair ${ }^{1}$, Rozlan Abdul Rahim ${ }^{1}$, Roszainora Setia ${ }^{1}$, Aileen Farida binti Mohd Adam ${ }^{1}$, \\ Norhayati Husin ${ }^{1}$, Elangkeeran Sabapathy ${ }^{1}$, Razita Mohamad ${ }^{1}$, Shahidatul Maslina Mat So'od ${ }^{1}$, Nurul Izatee Md \\ Yusoff $^{1}$, Razifa Mohd Razlan ${ }^{1}$, Nur Amalia Abd Jalil ${ }^{1}$, Salina Mohamed ${ }^{2} \&$ Norhafiza Abu Seman ${ }^{3}$ \\ ${ }^{1}$ Academy of Language Studies, Universiti Teknologi MARA (UiTM), Dungun Campus, Dungun, Malaysia \\ ${ }^{2}$ Likas Girls Secondary School, Kota Kinabalu, Malaysia \\ ${ }^{3}$ Faculty of Administrative Science and Policy Studies, Universiti Teknologi MARA (UiTM), Dungun Campus, \\ Dungun, Malaysia \\ Correspondence: Gopala Krishnan Sekharan Nair, Academy of Language Studies, Universiti Teknologi MARA \\ (UiTM), Dungun Campus, 23000 Dungun, Malaysia. Tel: 60-9-8400-8225/60-12-900-2602. E-mail: \\ gopa1792@tganu.uitm.edu.my
}

Received: December 30, $2011 \quad$ Accepted: February 14, $2012 \quad$ Published: July 1, 2012

doi:10.5539/ass.v8n8p74

URL: http://dx.doi.org/10.5539/ass.v8n8p74

\begin{abstract}
This study investigated the computer literacy and Internet usage levels in a semi-urban school in the East Coast of Terengganu. The study also investigates whether if there existed a significant relationship between computer literacy level and Internet usage skills. Further, the researcher also found out whether SES level and gender have a bearing on the computer literacy level of the sample. The instrument distributed to the students was found to have a strong reliability. Both the computer literacy and Internet usage levels of the sample were found to be satisfactorily high as indicated by the respective means. Correlation analysis was done to find out if there existed a significant relationship between computer literacy and Internet usage skills. It was found that a significant positive relationship exists between computer literacy and Internet usage $(\mathrm{r}=0.003, \mathrm{p}<0.05)$. Lastly the researcher used the comparison of means and t-testing to find out if income group or gender has a bearing on computer literacy of the sample. No significant difference in the literacy level was found between the two genders or between the income groups. This sample comes from a rural area, future researchers should replicate this study using an urban sample.
\end{abstract}

Keywords: computer literacy, ICT, internet usage levels, SES

\section{Introduction}

In a borderless world, Information and Communication Technology (ICT) has become a powerful tool to increase productivity and efficiency. It is indispensable for exploring the latest information. Before the emergence of information technology, people were introduced to computers mainly to run daily activities and transactions no matter where they are; whether they are in the office, education institutions or at home. However, at that time, the usage of computers was very limited because the technology was very new. Today, the usage of computer has expanded to various functions. Further development of telecommunications and networking has turned computers into communication via the internet and also as a mean to promote businesses, to search for information and for educational purposes.

The Malaysian government has been an enthusiastic supporter of ICT since the early nineties, and has developed a range of policies to encourage Malaysians to go online. More and more facilities were provided and currently, the Malaysian government is trying hard to make the citizens, Information Technology (IT) literate. As such, realizing the importance of ICT in education, the Ministry of Education (MOE) has taken a significant step to widen the usage of ICT among pupils by providing schools with ICT infrastructure. This is to bridge the gap between those who have access to facilities and those who have not. The Computer in Education (CIE) programme was launched and piloted in 60 secondary schools in 1992 for Form One and Form Two students. This programme was found to be beneficial to students in enhancing learning in the area of ICT. This study seeks to find out if the efforts by the government had borne fruit. The researcher investigated computer literacy and level of IT use in a sample of 70 respondents from a semi-urban school in the East Coast State in Terengganu. 


\section{Literature Review}

According to Hargittai (2005), experience with technology seems to be a good predictor of technology expertise. While some reseachers, Morahan-Martin and Shumacher (2007), have observed that owning a computer at home predicts the use of sophisticated technologies (it is worth mentioning and recognizing the fact that owning a computer at home does not involve being computer or Internet literate. The mere access to Internet does not entail a proper understanding by users of the information on the website.

This research also investigates a similar area. It seeks to find out whether computer literacy and internet usage levels are inter-related. In addition, it also seeks to find out whether extraneous factors such as family income have a bearing on internet usage and computer literacy.

If indeed factors such as poverty and income levels have a bearing on the use of computer, then the government must look seriously into poverty eradication so that no digital divide exists between the urban rich and the rural poor.

According to Lankshear and Knobel (2003), some of the new computer literacies include electronic gaming, synchronous and asynchronous communication, weblogs, webpages, and multimedia text production.

Andrews (2004), stated the new literacies in computer technologies including the environment in which students learn how to read and write with multiple modalities (graphics, animations, video, audio, hyperlinks, and print).

Nonetheless, and as Jewitt, (2006) suggested, the concept literacy has been fragmented into different types of literacy (visual, emotional, intellectual and digital) in an endeavor to adapt to the continuous new demands of new technologies.

In this regard, Korupp, Sylvia and Marc Szydlik (2005), said that computer literacy seems to be positively related to social activity and school performance, math and language skills, success in finding a job and hourly wages. It is with this in mind that the researcher intends to find out whether the respondents' social status, indicated by his income has an effect on his computer literacy level.

Poynton, (2005) recognized the necessity of looking at computer literacy based on a developmental approach, from kindergarten to adulthood. In this study, he focused especially on educational contexts. From kindergarten to late adolescence, gender differences in computer literacy have been associated with different factors: computer access, scarce presence of computer games, sensitive to gender differences, lack of role models, the way children learn to use computers and to interact with them, together with social expectations.

Other researchers who propose on the importance and benefits of computer skills are Oxbrow, (1998) who states that countries and societies should not ignore the need for imporving digital literacy and Stanley (2003), who claims that the availability of computer technology will motivate one to become computer literate.

Furthermore, supported by Turnbull and Lawrence (2002), who have reported that most students having a computer at home enjoyed using it and younger students are the ones who are very eager at using computers Eshet (2002). In addition, computer anxiety is acknowledged as the major factor related to computer literacy Bunz, Curry and Voon (2007). Winner and Langdon (1994), states that the Internet can be used to facilitate student-centered learning environment since it provides effective tools to present materials, resources to help students in accessing, analyzing as well as interpreting information. O'Hara, (1998) studied the attitudes and behaviour of fifth grade students using the internet and found increased motivation for the subject and the students had more focus on the learning task.

In a study, Follansbee et. al. (1996), have found that students who had access to material online produced better projects in terms of its presentation and integration of different perspectives. In other words, it tells us that the use of online materials help improve the quality of students' work or task. The use internet can help students access a lot of online materials related to the subjects or courses. Moreover, the materials online are contributed by the experts of the particular subject. Hence, those with online access demonstrated were more confident in conducting and presenting a topic means that the students show mastery of the subject.

\section{Methodology}

This study serves to establish the following;

[a] the respondents' level of computer literacy,

[b] the respondents' level of internet usage,

[c] the relationship between computer literacy level and Internet usage skills,

[d] the significant difference between the family income groups pertaining to computer literacy 
Furthermore, this study surveys on the computer literacy and the Internet usage skills in a semi-urban school in Terengganu. The findings may give an idea of the effectiveness of the government efforts so far. It may also helps to institute remedial measures if the literacy and IT skills are found to be wanting.

The study is focused on the usage of the Internet among Form One students of Sekolah Menengah Kebangsaan Seri Budiman, Kuala Terengganu.

In this study the population consists of Form One students of Sekolah Menengah Kebangsaan Seri Budiman, Kuala Terengganu. The population is 200 students. The sample comprises $30 \%$ of the population. This means that the sample has 70 respondents. The sampling technique used is the random sampling technique.

According to Minister of Education, from 2008 all students entering Form One would have a computer class as part of their time-table. Therefore, this is an opportunity to identify whether the students have picked up any expertise in Internet usage, and also to determine whether the computer class has enabled them to have a high level of computer literacy or thus computer literacy makes them more skilled in IT usage.

The questionnaire consists of three sections. Section A requires the demographic data on 4 items, namely gender, parents' monthly income, presence of computer at home and computer literacy of parents.

Section B is used to find the answer to research question one. It requires respondents to respond to 14 items so that their computer literacy level could be ascertained. Descriptive statistics will be used in Section A.

Section $\mathrm{C}$ requires respondents to identify their level of internet usage on 8 items. These questionnaires were given to 70 Form One students of Sekolah Menengah Kebangsaan Seri Budiman, Kuala Terengganu.

A pilot test was carried out on the $20^{\text {rd }}$ of September 2008 to test the reliability of the questionnaire. For this purpose the questionnaire was given out to 30 students form one students from one of the classes of the school where the sample was taken. However students from this class were not included in the sample of 70 students which was chosen earlier.

\subsection{Data Collection}

The researcher distributed the questionnaires to the respondents on the $25^{\text {th }}$ September 2008. As mentioned earlier the sample comprised 70 Form One students of Sekolah Menengah Kebangsaan Seri Budiman, Kuala Terengganu. The researcher was presence to orally explain the questions to the weaker respondents so that they will understand the questions well and the result will be accurate and precise. The questionnaires consisted of open-ended questions and questions are which involve the Likert scale. The questionnaires were collected soon after the respondents completed answering them.

\section{Results and Discussion}

\subsection{The Level of Computer Literacy of the Respondents}

The findings showed that, in general, the computer literacy level of the respondents in the sample was rather high. The findings indicate that the students have acquired a satisfactorily level of computer literacy. The sample comes from a semi-urban school of an East-Coast State. Descriptive analysis of their SES shows that they either in the low or middle income category. Most of the parents are not computer literate.

Notwithstanding the above, the students appear to have satisfactory computer literacy. It is reasonable to conclude that these skills were picked up in the computer class which is part of the curriculum of the Form One students. Therefore, the program introduced by the Ministry of Education (MOE) appears to show satisfactory results. The subject should be continued and attempts should be made to further improve the subject.

From the survey, only $42.9 \%$ of the respondents owned personal computers (PCs). In spite of this, the overall literacy level was high. This is a good indication that those without personal computers would still be able to pick up computer literacy through the school program.

The high level of computer literacy among the respondents is a positive sign and augurs well for the future of the nation. The findings showed that out of 70 respondents, only 6 were computer illiterate. The high number of students with computer knowledge is because of the intensive ICT courses provided by the school to these Form One students. They are taught basic computer usage and applications like MS Word, Power Point and MS Excel. There are a small number of students who do not know how to use the computer maybe due to the difficulties in understanding the main function of computer. This could easily be overcome by further assistance from the teacher. Therefore, this study has got diagnostic value whereby it is possible to identify pupils of low literacy level and carry out remedial measures on them. 


\subsection{The Level of Internet Usage of the Respondents}

The majority of the respondents had access to the Internet. Even if they do not have a PC at home, they still have the opportunity to do so at school.

The mean score for the level of internet usage is this study was 29.73 with a standard deviation of 2.64. The mean is much higher than the mid point value for Section $\mathrm{C}$ of the questionnaire. Therefore, the level of internet usage of the respondents was high.

Students use computer for Internet purposes and other applications. This indicates that the younger generation has started to use Internet in this Information Technology (IT) era and their level of awareness is a good sign for the development of ICT. This again shows that the newly introduced computer subject has been useful in enabling students to pick up IT skills.

Most of the respondents surf the Internet regularly. Most of them spend between five and ten hours on the internet especially on playing online games, watching movies and downloading online materials. Therefore, these types of material should be produced in greater number and made affordable to students. This study also shows that friends play a big part in influencing the students to learn Internet use. This is because with friends, they are more open and not embarrassed to ask when facing difficulties.

To further upgrade pupils' internet skills, parents and teachers should also play their role in teaching and helping children about Internet usage. Parent should have basic computer knowledge to be aware of Internet sites so that they know which websites are useful for their children. Obviously, they should also monitor their children's use of the Internet. This is important to avoid the youngsters from going into websites which are undesirable

Besides, parents and teachers can also play their part by giving them information on Internet use and providing proper guidance in Internet surfing. The majority of the students, who use the Internet, do so, to search for information. In this modern era, these students no longer have to go to libraries to find materials or sources because they can use Internet to get the latest, current and up-to-date information. As an example full text versions of free online journals can be found on the Internet. Students would need this when they are at the universities. Therefore, it is important that the skills are introduced to the students when they are still at school.

Besides searching for information, the numbers of students chatting on the Internet is also high. This is due to the existence of Internet Relay Chat (IRC) and ICQ (I seek you). These kinds of software can really attract people especially the young generation. It is an excellent way of making new acquaintances or even friends, not just in the country but also all over the world. They provide chat rooms, instant messaging and mailing lists that can connect groups of users to discuss a topic, share ideas and get to know each other. This kind of friend-making tool and communication is relatively cheap compared to making phone calls or sending non-electronic mail, locally or overseas.

The findings also indicated that the majority of respondents liked to play online games. Most of them spent between 5 to 10 hours on this service. They also download online sources such as ring tones and pictures. The majority of the respondents $(48.6 \%)$ were found to be familiar with at least three search engines. Another component that was tested in the instrument was composing and receiving email per week. Interestingly all of the respondents had composed and received emails in a week. These findings indicated that these young students know how to utilize the internet service.

\subsection{Relationship between Computer Literacy and Internet Usage}

The findings showed that there was a significant relationship between computer literacy and internet usage. The mean gain score for relationship between computer literacy and internet usage skill was lower (0.003) at the 0.01 level (1-tailed). This finding indicated that there appears to be a very weak but positive correlation between computer literacy and internet usage.

This shows that computer literacy maybe a prerequisite for acquiring Internet skills. Computer literacy gives a person the confidence to use the Internet and a computer literate person is more adept at Internet usage compared to one who is low on computer literacy.

Among the respondents with Internet experience, some owned computers at home. The number, even though small, still shows that there is IT awareness among these students and their families. This is a good indicator since Internet is relatively cheap for communication and information searching purposes.

Computer literacy assists in the acquiring in the Internet skills. Through Internet people with similar interests can share information with one another through electronic mail and chat rooms. E-mail enables radically new forms of 
worldwide human collaboration. Mailing list discussion and on-line conferencing allow them to work together on multiple projects that are interesting or related to their learning environment.

\subsection{Differences between Family Income Levels Pertaining to Computer Literacy}

This study also found that there is relatively no difference in computer literacy level among the different family income levels. Probably, nowadays even though the students do not have a computer at home they can still use it at other places such as the school or their friends' houses.

The computer subject in school is vital in ensuring that students of low SES, who do not have a computer at home, do not lose out on computer literacy and Internet usage skills. Since no difference have been found in literacy level of various income groups, one only conclude that the computer subject at school has played a role in ensuring that those of lower SES levels do not lose out on computer literacy, even if they do not have a computer at home.

Students who come from families of higher income groups usually have parents who are better qualified, of higher-status and hold better paying jobs. They may also have high levels of computer literacy and could teach their children more about Internet use. The students who come from a home of higher socio-economic level would be desirous of learning computer skill. Therefore they would be intrinsically motivated to learn computer literacy as it is perceived to be a means of better employment.

\section{Conclusion}

The findings of this study have implications for educational policy, teaching practice and further research. It is recommended that schools need to develop computer literacy policies that provide students with specialist courses and at the same time provides encouragement to students to gain greater computer literacy. The ICT Literacy Program should be implemented not only for Form One students but also to all levels of secondary students. In addition, schools need to consider the purchase of more computers and not only depend on the Ministry of Education to provide them with the equipment.

This study also stressed the need for the teachers to utilize and enhance the positive attitudes displayed by students towards the use of computers. At the same time, computer literacy teachers need to be concerned with the knowledge of computer systems.

Moreover, the school administrator should open the computer labs on weekends so that the students could use the computer to do their homework or assignments. This will also enable them to keep in contact with teachers via email.

Future researchers should employ stratified sampling rather than the random sampling employed here. They should work with the bigger sample and follow the progress of the respondents over a period of time like six months to a year, so that the progress can be noted.

In closing, it is hoped that this study would have produced some insights which may indicate to government, the importance of a viable computer curriculum at the school level. The promising results obtained from the sample should encourage the government to introduce the computer curriculum right at the primary school level. It is hoped that teachers teaching the computer subject and school heads also find this study useful in implementing the computer subject in school. Last but not least it hoped that parents and the society at large also realize the value of inculcating computer literacy among children at a very young age.

\section{References}

Andrews, R. (Ed.) (2004). The impact of ICT on literacy education. London: Routledge Falmer.

Bunz, U., Curry, C., \& Voon, W. (2007). Perceived versus actual computer-email-web fluency. Computers in human behavior, 23, 2321-2344. http://dx.doi.org/10.1016/j.chb.2006.03.008

Eshet, Y. (2002). Digital literacy: A new terminology framework and its application to the design of meaningful technology-based learning environments. In Proceedings of World Conference on Educational Multimedia, Hypermedia and Telecommunications 2002 (pp. 493-498). Chesapeake, VA: AACE.

Follansbee, S., Gilsdorf, N., Stahl, S., Dunfey, J., Cohen, S., Pisha, B., \& Hughes, B. (1996). The Role of Online Communication in Schools: a national study. Peabody, MA: Center for Applied Special Technology.

Hargittai, E. (2005). Survey measures of web-oriented digital literacy. Social Science Computer Review, 23(3), 371-379. http://dx.doi.org/10.1177/0894439305275911

Jewitt, C. (2006). Technology, literacy and learning. A multimodal approach. New Jersey: Routledge. 
Korupp, Sylvia E., \& Marc Szydlik. (2005). Causes and Trends of the Digital Divide. European Sociological Review, 21, 409-422. http://dx.doi.org/10.1093/esr/jci030

Lankshear, C., \& Knobel, M. (2003). New literacies: Changing knowledge and classroom learning. Buckingham: Open University Press.

Morahan-Martin, J., \& Shumacher, P. (2007). Attitudinal and experiential predictors of technological expertise. Computers in human behavior, 23, 2230-2239. http://dx.doi.org/10.1016/j.chb.2006.03.003

O'Hara, S. P. (1998). A case study of attitudinal effects of Internet use in a middle school integrated science curriculum. Paper presented at the Annual Meeting of the National Association for Research in Science Teaching. (ERIC Documnet Reproduction Service No. ED417978).

Oxbrow, N. (1998). Information Literacy the final key to an Information Society. Electronic Library, 16, 359-60. http://dx.doi.org/10.1108/eb045661

Poynton, T. A. (2005). Computer literacy across the lifespan: a review with implications for educators. Computers in human behavior, 21, 861-872. http://dx.doi.org/10.1016/j.chb.2004.03.004

Stanley, L.D. (2003). Beyond access: Psychosocial barriers to computer literacy. The Information Society, 19, 407-416. http://dx.doi.org/10.1080/715720560

Turnbull, M., \& Lawrence, G. (2002). Computers make sense according to brain research..but what do students think? Canadian Association of Second Language Teachers. Retrieved Oct. 11, 2008, from http://www.caslt.org/

Winner, Langdon. (1994). The Virtually Educated. Technology Review, 97(4), 66. 